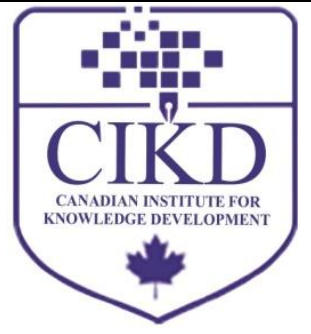

\title{
Examination of the Effects of Emotional Intelligence and Authentic Leadership on the Employees in the Organizations
}

\author{
Zafer Adigüzel $^{1 *}$, Eda Kuloğlu ${ }^{2}$ \\ ${ }^{1}$ Istanbul Medipol University, School of Business and Management Sciences, Istanbul, Turkey \\ ${ }^{2}$ Istanbul Medipol University, College of Health Sciences, Istanbul, Turkey
}

\section{Keywords: \\ Authentic Leadership, \\ Emotional Intelligence, Organizational Identity, \\ Goal-Oriented \\ Performance, Emotional \\ Commitment.}

\section{Received}

30 June 2018

Received in revised form

25 October 2018

Accepted

19 November 2018

Correspondence:

zadiguzel@medipol.edu.tr

\begin{abstract}
In the highly competitive environment of the business world, organizations implement human resource policies and practices to increase the motivation and performance of employees. Efforts to keep employee turnover at minimum levels are directly proportional to employee satisfaction and their willingness to stay in the organization. Employees' dissatisfaction, leaders' attitudes and behaviours, human resources policies determine the life of the organizations. The increase in the employment turnover rate can decrease the performance of the organization, bring additional costs and cause employee trainings to be ineffective. In particular, the qualified employees can easily leave the organization if they do not like the management approach leads to the formation of different management understandings and perspectives. The leadership style of the managers and the human resources policies can shape the future of the organizations. Therefore, it is important to conduct studies in this field to help the senior managers to make decisions and demonstrate their leadership roles. The sample of this study consists of 498 white-collar employees working in the private and public sector. The findings were subjected to factor and reliability analyses by using IBM SPSS 23 program. The hypotheses were tested by regression analysis and the results were evaluated and presented accordingly.
\end{abstract}

(C)AIMI Journals

The importance of the authentic leader and his/her impact on the attitudes and behaviours of his/her followers are known, it is also determined that there is a significant relationship between emotional commitment and authentic leadership in terms of organizational outcomes (Gardner, Cogliser, Davis, \& Dickens, 2011). Emotional commitment is about an employee's understanding and acceptance of organizational goals and values and his/her personal and 
emotional attachment to the organization (Meyer \& Allen, 1991). In other words, emotional commitment creates feelings of belonging to the organization. In today's world, one of the most important issues for the organizations is to keep employee turnover rate at minimum level by gaining emotional commitment of the employees. The authentic leaders can be effective in increasing emotional commitment levels of the employees by establishing high quality relationships based on positive social changes (Ilies, Morgeson, \& Nahrgang, 2005). Authentic leaders behave honestly and transparently, avoid prejudicial decisions and build trust-based relationships, which facilitates social change and encourages stronger employee commitment (Avolio \& Gardner, 2005).

Apart from the effect of authentic leadership, the other important concept is 'emotional intelligence' for the organizations. Emotional intelligence is about managing emotions and helping people to stay calm and to think correctly. By doing so, individuals' personal and social competencies can be improved. In this context, the concept of emotional intelligence has been developed. Individuals with high emotional intelligence can perform better at the workplace, establish good relationships, and have positive social personality. Goleman (1995) defines emotional intelligence as "the potential to have a good command of self-awareness, self-management, social awareness and relationship management skills." The term 'Emotional Intelligence' was introduced by Salovey and Mayer in 1990 and they argued that the emotions revolves around capacity of reasoning and can improve thinking (Sadri, 2012). The concept of emotional intelligence suggests that two different mental processes, thinking and feeling, actually work together (Kerr, Garvin, Heaton, \& Boyle, 2006)

A study on the concepts of authentic leadership and organizational identity indicates that the trust created by leaders - a feature of Authentic Leadership - develops organizational identity of the employees (Çeri-Booms, 2012). Performance-oriented employees have higher motivation to reach their performance standards, as long as they do not carry the risk of unsatisfactory skills compared to other employees (Janssen \& Van Yperen, 2004). Accordingly, a leader's influence can lead high-performance-oriented employees to selfpressure themselves to perform well in order to protect their sense of value (Rawsthorne \& Elliot, 1999). Therefore, the effects of authentic leadership and emotional intelligence on organizations, particularly on employees, should be explored. Constantly changing needs and desires also cause changes in attitudes and behaviours of the individuals towards the organizations and this situation lays the groundwork for the generation of new theories.

\section{Authentic Leadership}

Authentic leadership has emerged as an important and popular leadership style in recent years in response to a number of high-profile leadership initiatives (Caza \& Jackson, 2011). Both popular media and academic research have paid particular attention to the issue (Gardner, et al., 2011). In literature, authentic leadership are defined as a series of consecutive behaviours related to making ethical decisions and using information (Avolio et al., 2004). In a recent review study, Gardner et al. (2011) summarized the findings of empirical studies about followers' responses to Authentic Leadership and subsequent studies were linked to each other (Hsiung, 2012). More explicit conceptualization and experimental accuracy, especially at the level of analysis, is required to clarify the relevant processes in order to improve the theory of 
authentic leadership (Cho \& Dansereau, 2010). Authenticity in the concept of authentic leadership goes beyond the idea of "self-realization". Authentic functioning arises from one's personal thoughts, emotions, desires, strengths and weaknesses, objective processing of selfsufficient information, actions appropriate to personal values, beliefs and rewards, fines and awareness of the satisfaction of others (Kernis, 2003).

Since its conceptualization, empirical research has proven the critical role of authentic leadership in promoting improved organizational and employee outcomes (Gardner et al., 2011). Empirical evidence consistently confirms that high-level authentic leaders form a link that generates positive business outcomes, such as stronger organizational commitment and organizational citizenship behaviour of the employees (Azanza, Moriano, Molero, \& Lévy Mangin, 2015). Moreover, when the positive relationship between employee attitudes and organizational outcomes are taken into account, it has been proved that authentic leadership has a direct and positive effect on organizational performance (Wong \& Laschinger, 2013). Recently, some studies have examined Authentic Leadership at the group level (Hsiung, 2012). However, we cannot comment on the existence of any study that examines the effects of both group-based and individual-based Authentic Leadership. Furthermore, there are also theoretical and methodological questions arising from the analysis of the Authentic Leadership at the group level and therefore we propose an alternative study which addresses these questions and presents a clear pathway for future theory development. In the present study, we deal with the individual and group based effects of authentic leadership by explaining theoretically and quantitatively.

\section{Emotional Intelligence}

Emotional Intelligence is a field that emerged during psychological and behavioural research. The concept of emotional intelligence comes from term "social intelligence", which is defined as the ability to deal with people intelligently in human relationships (Majeed, Ramaya, Mustamil, Nazri, \& Jamshed, 2017). In the early 1980s, scientists began to conceptualize emotions within the framework of emotional intelligence, because it included emotions and emotional expressions. Firstly, the idea of Emotional Intelligence was introduced by Salovey and Mayer (1990) and supported by Boyatzis, Goleman, and Rhee, (2000) and they defined Emotional Intelligence as the ability to deal with emotions. Emotional Intelligence involves interconnected emotional skills: these are the perception, analysis, recognition, and management of emotions of one's self and others (Mayor \& Salovey, 1997). Antonakis, Ashkanasy, and Dasborough (2009) argue that emotional intelligence is not required for proper leadership and correct leaders can meet emotional needs with basic behaviours and leadership role. However, Jordan and Troth's (2004) study state that emotional intelligence is a fundamental principle in leadership to promote relationship in the workplace. Carmeli (2003) established that there is a relationship between emotional intelligence and the way senior executives manage their employees. Managers with higher emotional intelligence not only manage stress but they can also solve problems that may cause stress. In another study, it was explained that the employees with emotional intelligence skills have desire to establish high quality relationships in the workplace. 
Employees who have high scores of emotional intelligence build and maintain relationships with higher quality (Lopes, Salovey, \& Straus, 2003). People with higher Emotional Intelligence perform better than those with lower Emotional Intelligence in life (Bar-On, 1997). They are able to understand themselves and other people better, socialize more, communicate more and cope with challenging changing situations. At the same time, high Emotional Intelligence improves the physical and psychological health of people and provide better academic and business performance (Bar-On \& Parker, 2000). Furthermore, Emotional Intelligence is also negatively associated with job and occupational stress (Nikolaou \& Tsaousis, 2002). Therefore, many scholars suggest that Emotional Intelligence is an important component of effective leadership (Sadri, 2012). Emotional intelligence 'represents an important competence in effective organization and team performance, today' (Melita Prati, Douglas, Ferris, Ammeter, \& Buckley, 2003). In this study, we examine the intervening variable effects of emotional intelligence on the leadership role and also on the commitment, performance and organizational identity of the employees.

\section{Organizational Identity}

There is a common opinion in the literature about the benefits of having a high level of organizational identity which is defined as 'an employee see himself/herself as a part of the organization' (Dutton, Dukerich, \& Harquail, 1994). In the service sector, if the employees have high level of organizational identities, it positively affects his/her sales performance, and perceptions of customer service quality and customer spending (Bell \& Menguc, 2002). In the literature, it has been stated that organisational identity encourages beneficial behaviours of the employees, such as being cooperative, being customer-oriented and reduce intentions to leave work (Wieseke, Ullrich, Christ, \& Van Dick, 2007). The high volume of work in the service sector means that any activity that can help to increase organizational identity and keep employees in the organisation is highly important (Tang, Liu, Oh, \& Weitz, 2014). Organizational identity can help to reduce intention to leave work, and also, it is argued that it is positively associated with a number of critical outcomes such as higher employee performance and accepting extra organizational duties (Riketta, 2005). Leaders are seen as the representatives of the organisation by his/her followers; therefore, trust in leaders is positively related to organizational identity (Schaubroeck, Peng, \& Hannah, 2013).

A widely accepted view is that there is a coherence between organizational identity and individual and collective identities, and it is defined with terms such as sense of unity between employees and their organizations (Gutierrez, Howard-Grenville, \& Scully, 2010). Organizational identity indicates organization's perception of the world, how much the organization reflects the worldview of the individuals and what are the values and emotions related to the meaning of the organizational membership (Oakes, Haslam, \& Turner, 1994). According to Ashforth and Mael (1989), a positive and distinctive organizational identity presented by the managers does not only ensure support and loyalty of the organizational members but also bring the support and loyalty of other key elements such as shareholders and customers. Glavas and Godwin (2013) stated that 'promoting organizational identity is a critical task for ensuring organizational effectiveness'. For this reason, organizations make significant efforts to develop organisational identification of the members in order to achieve 
effective results (Shamir \& Kark, 2004). In this study, we examine the relationship between leadership and emotional intelligence to explain organizational identity, which is very important concept for the organizations.

\section{Goal-Oriented Performance}

Carol Dweck (1986) is one of the pioneers of goal-oriented studies. Her original studies are in the field of education. Dweck examined the reactions of the children to failure and focuses on whether a child has a reaction to the mentors or have a desperate response pattern (Deiner \& Dweck, 1978). Vandewalle and Cummings (1997) conducted an extended study and examined the work of Dweck and her colleagues in terms of goal-orientation. Employees with a learning goal-orientation accept and pursue challenging tasks and are more likely to hold challenging goals (Vandewalle, Brown, Cron, \& Slocum, 1999). It is understood that the employees, who try to show their talents to achieve positive feedback and a positive perception, have a goalorientation.

There are two different tendencies among employees in terms of goal-oriented performance. Some employees prefer a learning orientation that defines mastership as a success, and some employees prefer a performance orientation that defines performance as a success (Dweck, 1986). Performance-oriented individuals demonstrate their talents in the form of performance, reach success by achieving the goals and they do not like to face difficult situations and feel that they do not have necessary competence in the face of difficult situations (Kim \& Lee, 2013). Goal-Orientation plays an important role in human resource decisions, such as recruitment (Rynes \& Gerhart, 1990), selection (Roberson \& Alsua, 2002), and performance evaluation (VandeWalle \& Cummings, 1997; Brown, 2001). In addition, goal orientation can also affect certain performance levels, for example, sales performance (Kohli, Shervani, \& Challagalla, 1998), task performance (Steele, Beauregard, Hoover, \& Schmidt, 2000) and educational performance (Brett \& VandeWalle, 1999). However, there is only few studies on the factors that influence the goal-orientation of employees, especially in the service sector.

However, there are large number of studies that focus on the relationship between determination of a purpose and individual job performance in terms of goal-orientation (Latham \& Locke, 1991). Goal-orientation is a success motivation theory that categorizes how people approach their tasks. Goal-oriented individuals approach difficult tasks with the intention of exhibiting relatively good performance. In order to combine leaders and goaloriented performance of employees in a conceptual framework, it is necessary to assess how the leaders influence the Goal-orientation behaviours of the employees. Dragoni (2005) suggests that leadership behaviour has influence on the goal-oriented employees. Therefore, in this study, we examine the effects of authentic leadership and emotional intelligence on the performance-oriented behaviours of the employees, which is very important for the organizations in intense competitive environments.

\section{Emotional Commitment}

Positive emotional commitment improves the work-life balance of the employees and eliminates problems of role conflicts that create less supportive working environments (Moon, 
Hur, Ko, Kim, \& Yoon, 2014). The employees with an emotional commitment are happy to be a member of the organization and feel as a part of the organization and do not consider to resignation (Meyer \& Herscovitch, 2001). Meyer, Stanley, Herscovitch, \& Topolnytsky (2002) argue that emotional commitment has much stronger associations with the individual and the organizational variables than the other types of commitment (normative and continuation commitment). If the leaders give too much tasks or responsibilities to their subordinates, it can weaken the loyalty of employees. Meyer and Allen (1997) state that over workload negatively affects employees' emotional commitment. Maxwell and Steele (2003) explain that if the responsibilities and workloads remains steady, their organizational commitments will be affected positively, therefore it is determined that there is a negative relationship between workload and organizational commitment. Synder and Spreitzer (1984) also mention about the existence of a significant and positive relationship between emotional commitment and internal motivation. Accordingly, if employees' emotional commitment increases, their internal motivation increases, too. Employee with emotional commitment actively and voluntarily participates in the activities in the direction of organizational goals. In the study conducted by Schneider, Rief, and Guzzo (1996), it is stated that the factor that motivates and directs the efforts of employees is the emotional commitment to the organization. Emotional Commitment is not a commitment depends on external factors, but it is a form of self-generated commitment based on internal factors. People who have emotional commitment tell that 'I work here because it is a great and fun business environment' (Duarte, 2015). As demonstrated in Figure 1 , there are three important elements of emotional commitment based on the principle that an employee should express himself/ herself with the organization (Gürbüz, 2006);

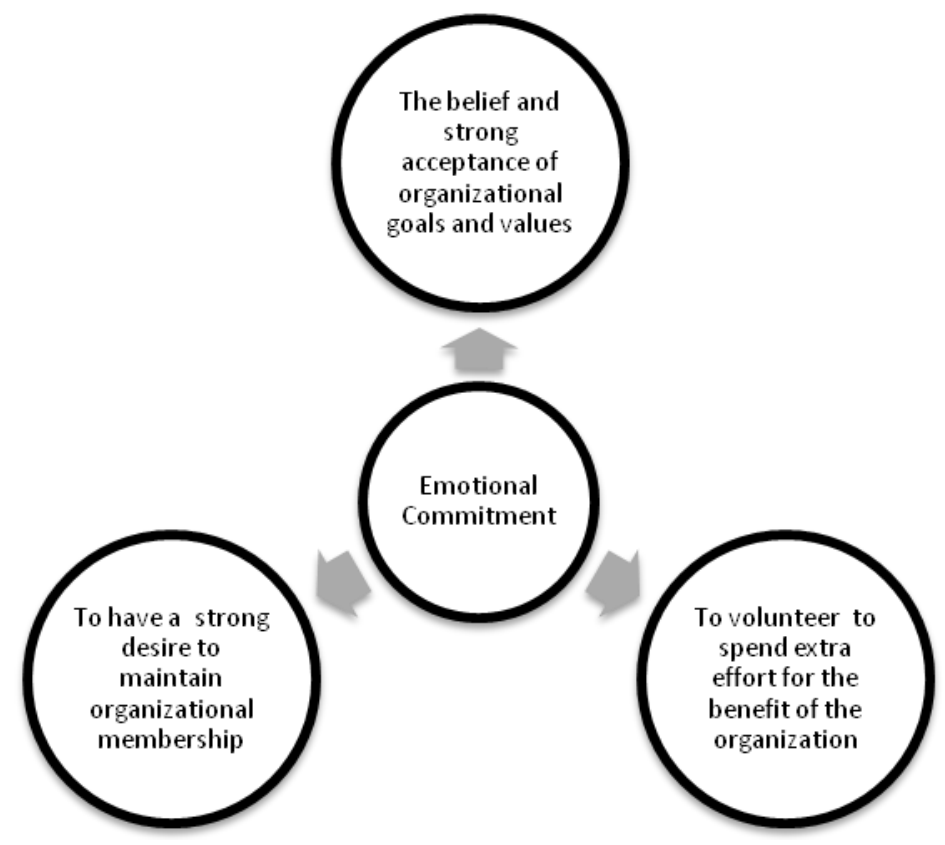

Figure 1. Three important factors of emotional commitment

Emotional commitment is defined by Allen and Meyer (1990) as an employee who feels emotional affiliation towards the organization and identifies himself/herself with the 
organization. In this context, the employees with strong emotional commitment adopt the values, goals and objectives of their organization; they want to remain a part of the organization. In this study, we also examine whether there is any relationship between emotional commitment of the employees and authentic leadership and emotional intelligence.

\section{Method}

A survey was conducted with 498 employees in line with the purpose of the study. Data was evaluated using SPSS 23.00 Statistical Software Program and the demographic information was subject to 'descriptive' analysis. Likert scale questions were subjected to factor and reliability analyses. Correlation analysis was conducted to examine the relationships between variables; Regression analysis was performed to test the hypotheses. Authentic Leadership scale was measured with 14 questions developed by Neider and Schriesheim in 2011. Emotional Intelligence scale were adapted from the scale used by Bar-On, R. (2001) and was measured by 17 questions. Organizational Identity scale was measured with 6 questions developed by Mael ve Ashforth (1992). Goal-Oriented Performance scale was measured by 8 questions developed by Kim and Lee (2013). Emotional Commitment scale was measured by 8 questions developed by Ağca and Ertan (2008)

\section{Findings}

The sample of our Likert scale survey was consisted of 498 white-collar employees working in different departments of private and public organizations. Our survey was conducted by the participation of 216 female employees and 282 male white-collar employees. Ages of the participants of the survey were distributed as; $16 \%$ between the ages of 18-25 (78 participants), 25\% between 26 -30 (122 participants), 24\% between 31 -35 (118 participants), $19 \%$ between 36 - 40 (95 participants), 13\% between 41 - 45 (64 participants) and 4\% of the participants were 46 years and over ( 21 participants). $40.9 \%$ of the employees were working in the public sector (222 employees) and $59.1 \%$ were in the private sector (276 employees). The employees were working for their organizations as; $15 \%$ for less than 1 year (76 employees), $26 \%$ for 1-3 years (128 employees), $25 \%$ for 4-7 years (123 employees), $16 \%$ for 8-10 years (82 employees), $18 \%$ for 10 years and over ( 89 employees). $1.6 \%$ of the participants had primary school education ( 8 participants), $4.6 \%$ had high school or similar education (23 participants), $16.8 \%$ had vocational school/associate degree (84 participants), $68 \%$ had university degree (338 Participants), 9\% of them had graduate degree. (45 Participants).

\section{Research Framework}

Based on the literature review, our research model was composed with independent variables of Authentic Leadership and Emotional Intelligence and dependent variables of Organizational Identity, Goal-Oriented Performance and Emotional Commitment. Our study adapted a quantitative approach because the data was analyzed to determine the relationship between statistical concepts. In a quantitative research, we use independent variable(s) to determine their effect on the dependent variable (Thomas Nelson, \& Silverman, 2005). The research model is presented in Figure 2. 


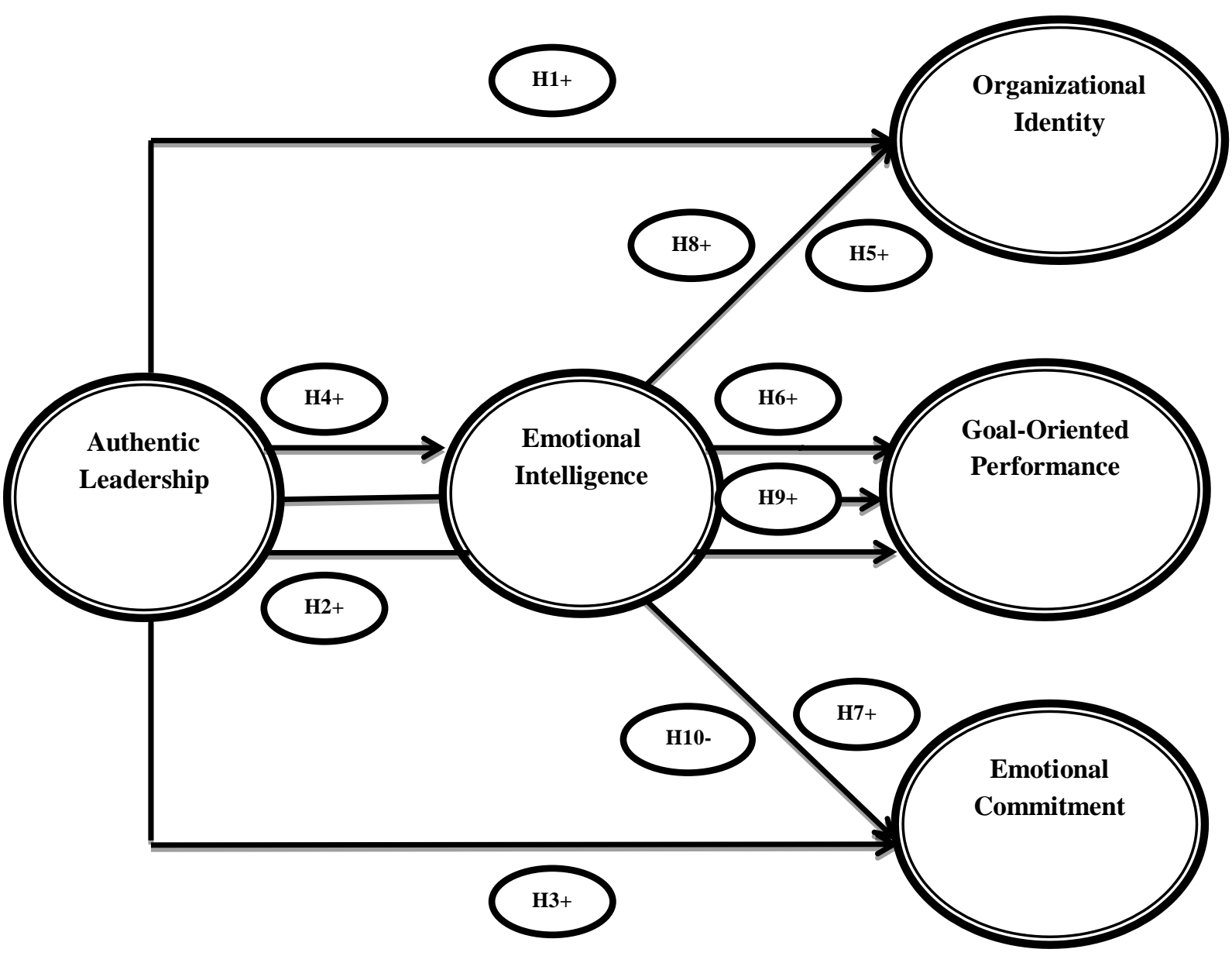

Figure 2. Research model

In our study, the variables were prepared according to the 5 point Likert scale and were measured by a questionnaire of 53 questions. Variables of Authentic Leadership, Emotional Intelligence, Organizational Identity, Goal-Oriented Performance and Emotional Commitment were subjected to factor analysis. As a result, 13 questions did not show factor distribution. They loaded into different factors and decreased the reliability and therefore they were subtracted from the scale. The remaining 40 questions were distributed into 5 factors. The variables that were subjected to factor analysis with their factor loads are shown in Table 1.

Büyüköztürk (2005) defines factor analysis as a multivariate statistical method aiming to discover a small number of unrelated but conceptually significant new variables (factors, dimensions) by bringing related variables together. 
Table 1

KMO and Bartlett's Test / Rotated Component Matrix ${ }^{a}$

\begin{tabular}{|c|c|c|c|c|c|c|}
\hline \multicolumn{7}{|c|}{ KMO and Bartlett's Test } \\
\hline \multicolumn{2}{|c|}{ Kaiser-Meyer-Olkin Measure of Sampling Adequacy. } & \multicolumn{3}{|c|}{.95} & & \\
\hline \multirow{3}{*}{ Bartlett's Test of Sphericity } & Approx. Chi-Square & \multicolumn{3}{|c|}{7934.09} & & \\
\hline & df & \multirow{2}{*}{\multicolumn{3}{|c|}{378}} & & \\
\hline & Sig. & & & & & \\
\hline \multicolumn{7}{|c|}{ Rotated Component Matrix ${ }^{\mathrm{a}}$} \\
\hline & & \multicolumn{5}{|c|}{ Component } \\
\hline & & 1 & 2 & 3 & 4 & 5 \\
\hline EC4. The organisation I work for 1 & very special meaning for me. & .866 & & & & \\
\hline EC 3. I feel emotionally committe & e organisation I work for. & .842 & & & & \\
\hline EC 5. I feel like a part of this orgat & tion. & .817 & & & & \\
\hline EC 2. I have a strong sense of belo & $\mathrm{ng}$ to the organisation I work for. & .799 & & & & \\
\hline EC 7. I think one should be proud & e an employee of this organisation. & .762 & & & & \\
\hline DB8. I accept the objectives of thi & ganisation. & .740 & & & & \\
\hline DB1. I see the problems of the org & ation as my own problems. & .727 & & & & \\
\hline EC 6. I see the job at this organisa & as my own private job. & .726 & & & & \\
\hline $\begin{array}{l}\text { AL3. In the organisation I work fo } \\
\text { the employees. }\end{array}$ & ir managers clearly express their ideas and thoughts to & & .827 & & & \\
\hline $\begin{array}{l}\text { AL1. In the organization I work fo } \\
\text { actions }\end{array}$ & ere is a coherence between our managers' beliefs and & & .824 & & & \\
\hline $\begin{array}{l}\text { AL4. In the organization I work fo } \\
\text { their basic beliefs. }\end{array}$ & ur managers express their ideas in a way that supports & & .815 & & & \\
\hline $\begin{array}{l}\text { AL2. In the organisation I work fo } \\
\text { before making any decisions. }\end{array}$ & ur managers listen to employees with different ideas & & .779 & & & \\
\hline $\begin{array}{l}\text { AL5. In the organisation I work fo } \\
\text { decisions. }\end{array}$ & ur managers also use their basic beliefs when making & & .756 & & & \\
\hline $\begin{array}{l}\text { AL6. In the organisation I work fo } \\
\text { views and perceptions. }\end{array}$ & ur managers encourage employees to present different & & .755 & & & \\
\hline $\begin{array}{l}\text { AL8. In the organisation I work fo } \\
\text { employees. }\end{array}$ & ur managers clearly share information with the & & .748 & & & \\
\hline $\begin{array}{l}\text { AL7. In the organisation I work fo } \\
\text { against their beliefs }\end{array}$ & ur managers are very resistant to doing things that are & & .744 & & & \\
\hline $\begin{array}{l}\text { AL10. In the organisation I work } \mathrm{f} \\
\text { objective decisions. }\end{array}$ & our managers analyse the relevant data before making & & .731 & & & \\
\hline $\begin{array}{l}\text { AL11. In the organisation I work } \mathrm{f} \\
\text { internal moral principles. }\end{array}$ & our manager direct his/her actions / behaviours with & & .725 & & & \\
\hline AL12. In the organisation I work $f$ & our managers clearly state what they want. & & .649 & & & \\
\hline $\begin{array}{l}\text { AL13. In the organisation I work } f \\
\text { employees. }\end{array}$ & our managers are very aware of their effects on the & & .572 & & & \\
\hline $\begin{array}{l}\text { AL14. In the organisation I work f } \\
\text { strengths and weaknesses. }\end{array}$ & our managers show that they are aware of their & & .566 & & & \\
\hline OI3. The success of the organisatic & work for is also my achievement. & & & .632 & & \\
\hline OI5. I feel embarrassed if the med & iticizes the organisation I work for. & & & .627 & & \\
\hline OI2. I am very interested in what $\mathrm{c}$ & rs think about the organisation I work for. & & & .560 & & \\
\hline EI3. In the organisation I work for & eally understand how I feel. & & & & .835 & \\
\hline EI4. In the organisation I work for & now when I am happy. & & & & .833 & \\
\hline EI5. In the organisation I work for & nderstand my friends' feelings from their behaviours. & & & & .820 & \\
\hline EI8. In the organisation I work for & nderstand the feelings of people around. & & & & .808 & \\
\hline EI6. In the organisation I work for & vell observe the feelings of others. & & & & .797 & \\
\hline EI12. In the organisation I work fo & always encourage myself to show my best effort. & & & & .784 & \\
\hline EI7. In the organisation I work for & $\mathrm{m}$ sensitive to the feelings of others. & & & & .769 & \\
\hline $\begin{array}{l}\text { EI2. In the organisation I work for } \\
\text { feelings well. }\end{array}$ & the institution I work with, I understand my own & & & & .768 & \\
\hline $\begin{array}{l}\text { EI9. In the organisation I work for } \\
\text { takes to reach them. }\end{array}$ & lways set goals for myself and I try to do whatever it & & & & .760 & \\
\hline EI10. In the organisation I work fo & always say that I am a competent enough. & & & & .749 & \\
\hline EI11. In the organisation I work fo & can motivate myself. & & & & .685 & \\
\hline $\begin{array}{l}\text { OOP7. In the organisation I work } \\
\text { colleagues. }\end{array}$ & I feel smart when I can do something better than my & & & & & .773 \\
\hline $\begin{array}{l}\text { OOP4. In the organisation I work } \\
\text { mistakes. }\end{array}$ & I feel very smart when I do something without making & & & & & .717 \\
\hline $\begin{array}{l}\text { OOP5. In the organisation I wo } \\
\text { accepting the task. }\end{array}$ & want to make sure that I can do the jo & & & & & .684 \\
\hline
\end{tabular}




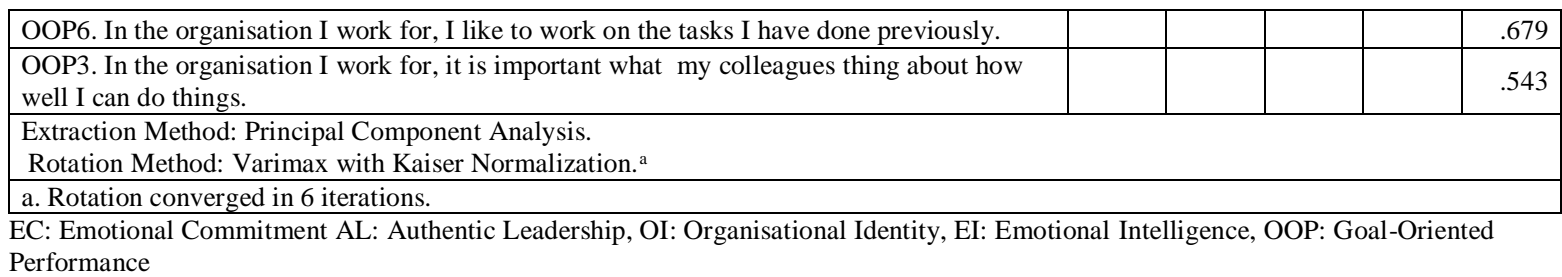

Reliability analysis is defined as the internal consistency of the measurement which is about the average relation between the questions. In the literature, the Cronbach's alpha coefficient of .50 and above is accepted as sufficient by Nunnally (1978) and Hair, Robert, and David (2000). Reliability means that a measurement tool shows consistent results in all cases (Bell, 1993). When the literature is examined, it is seen that reliability is checked before the validity in scale development studies. If the scale is not reliable, it will not be valid as well. Therefore, there is no need to conduct a validity test for a scale that does not fulfil reliability standards (Çelik \& Bindak, 2005). Table 2 presents reliability analysis, descriptive statistics, and correlations.

Table 2

Reliability Analysis / Descriptive Statistics / Correlations

\begin{tabular}{lccc}
\hline VARIABLES & Number of Questions & Cronbach Alfa $(\alpha)$ Values \\
\hline Emotional Commitment & 8 & .96 \\
Authentic Leadership & 13 & .92 & .75 \\
Organisational Identity & 3 & .95 & .89 \\
Emotional Intelligence & 11 & & \\
Goal-Oriented Performance & 5 & $5 D$ & 299 \\
\hline & Descriptive Statistics & 1.00 & 299 \\
\hline Authentic Leadership & $M$ & .82 & 299 \\
Emotional Intelligence & 3.73 & .90 & 299 \\
Organisational Identity & 4.10 & .88 & .98 \\
Goal Oriented Performance & 4.04 & .98 & 299 \\
Emotional Commitment & 4.15 & & \\
\hline
\end{tabular}

Table 2 (Continued)

\begin{tabular}{|c|c|c|c|c|c|c|}
\hline \multicolumn{7}{|c|}{ Correlations } \\
\hline & & $\begin{array}{l}\text { Authentic } \\
\text { Leadership }\end{array}$ & $\begin{array}{c}\text { Emotional } \\
\text { Intelligence }\end{array}$ & $\begin{array}{l}\text { Organisational } \\
\text { Identity }\end{array}$ & $\begin{array}{c}\text { Goal } \\
\text { Oriented } \\
\text { Performance }\end{array}$ & $\begin{array}{c}\text { Emotional } \\
\text { Commitment }\end{array}$ \\
\hline \multirow[t]{3}{*}{$\begin{array}{l}\text { Authentic } \\
\text { Leadership }\end{array}$} & $\begin{array}{l}\text { Pearson } \\
\text { Correlation }\end{array}$ & 1 & $.51^{* *}$ & $.567^{* *}$ & $.49^{* *}$ & $.51^{* *}$ \\
\hline & Sig. (2-tailed) & & .000 & .000 & .000 & .000 \\
\hline & $\mathrm{N}$ & 299 & 299 & 299 & 299 & 299 \\
\hline \multirow[t]{3}{*}{$\begin{array}{l}\text { Emotional } \\
\text { Intelligence }\end{array}$} & $\begin{array}{l}\text { Pearson } \\
\text { Correlation }\end{array}$ & $.51^{* *}$ & 1 & $.44^{* *}$ & $.51^{* *}$ & $.34^{* *}$ \\
\hline & Sig. (2-tailed) & .000 & & .000 & .000 & .000 \\
\hline & $\mathrm{N}$ & 299 & 299 & 299 & 299 & 299 \\
\hline \multirow[t]{3}{*}{$\begin{array}{l}\text { Organisational } \\
\text { Identity }\end{array}$} & $\begin{array}{l}\text { Pearson } \\
\text { Correlation }\end{array}$ & $.56^{* *}$ & $.44^{* *}$ & 1 & $.57^{* *}$ & $.63^{* *}$ \\
\hline & Sig. (2-tailed) & .000 & .000 & & .000 & .000 \\
\hline & $\mathrm{N}$ & 299 & 299 & 299 & 299 & 299 \\
\hline $\begin{array}{l}\text { Goal } \\
\text { Oriented }\end{array}$ & $\begin{array}{l}\text { Pearson } \\
\text { Correlation }\end{array}$ & $.49^{* *}$ & $.51^{* *}$ & $.57^{* *}$ & 1 & $.63^{* *}$ \\
\hline \multirow[t]{2}{*}{ Performance } & Sig. (2-tailed) & .000 & .000 & .000 & & .000 \\
\hline & $\mathrm{N}$ & 299 & 299 & 299 & 299 & 299 \\
\hline \multirow[t]{3}{*}{$\begin{array}{l}\text { Emotional } \\
\text { Commitment }\end{array}$} & $\begin{array}{l}\text { Pearson } \\
\text { Correlation }\end{array}$ & $.51^{* *}$ & $.34^{* *}$ & $.63^{* *}$ & $.63^{* *}$ & 1 \\
\hline & Sig. (2-tailed) & .000 & .000 & .000 & .000 & \\
\hline & $\mathrm{N}$ & 299 & 299 & 299 & 299 & 299 \\
\hline
\end{tabular}


Statistics is a science that deals with the collection, classification, presentation and interpretation of numerical data (Johnson, 1980). It is a method that aims to make the collected data to be meaningful using scientific methods (Linquist, 1989). Descriptive statistics include methods and techniques for collecting, describing and presenting numerical data.

As a result of the correlation analysis (Table 2), it was determined that there are significant relationships between the Authentic Leadership, Emotional Intelligence and Organizational Identity, Goal-Oriented Performance and Emotional Commitment. The positive and significant relationships between the variables indicate that they are important variables in establishing positive climate in organizations. If organizations want to be successful in intense competitive environment, they should give importance to creating organizational identity and positive emotional commitment of the employees. At the same time, there is a significant impact when the performance of employees is directly proportional to the performance of the organizations. Regression analysis was used to test predicted research hypotheses and the results are shown in Table 3.

Table 3

Effects of Independent Variables on Dependent Variables According to Regression Analysis

\begin{tabular}{|c|c|c|c|c|c|}
\hline Independent Variables & Dependent Variables & Standart $\beta$ & $p$ & Adjusted R2 & $F$ \\
\hline $\begin{array}{l}\text { Authentic } \\
\text { Leadership }\end{array}$ & $\begin{array}{l}\text { Organisational } \\
\text { Identity }\end{array}$ & $.56^{* * *}$ & .000 & .31 & 140.89 \\
\hline $\begin{array}{l}\text { Authentic } \\
\text { Leadership }\end{array}$ & $\begin{array}{l}\text { Goal } \\
\text { Oriented } \\
\text { Performance }\end{array}$ & $.49 * * *$ & .000 & .23 & 94.25 \\
\hline $\begin{array}{l}\text { Authentic } \\
\text { Leadership }\end{array}$ & $\begin{array}{l}\text { Emotional } \\
\text { Commitment }\end{array}$ & $.51 * * *$ & .000 & .26 & 105.54 \\
\hline $\begin{array}{l}\text { Authentic } \\
\text { Leadership }\end{array}$ & $\begin{array}{l}\text { Emotional } \\
\text { Intelligence }\end{array}$ & $.51 * * *$ & .000 & .26 & 106.97 \\
\hline $\begin{array}{l}\text { Emotional } \\
\text { Intelligence }\end{array}$ & $\begin{array}{l}\text { Organisational } \\
\text { Identity }\end{array}$ & $.44 * * *$ & .000 & .19 & 71.40 \\
\hline $\begin{array}{l}\text { Emotional } \\
\text { Intelligence }\end{array}$ & $\begin{array}{l}\text { Goal } \\
\text { Oriented } \\
\text { Performance }\end{array}$ & $.51 * * *$ & .000 & .25 & 104.77 \\
\hline $\begin{array}{l}\text { Emotional } \\
\text { Intelligence }\end{array}$ & $\begin{array}{l}\text { Emotional } \\
\text { Commitment }\end{array}$ & $.34 * * *$ & .000 & .11 & 41.12 \\
\hline
\end{tabular}

\section{Supported and Unsupported Hypotheses According to Regression Analysis Results}

Regression analysis was used to test predicted research hypotheses. The supported 4 hypotheses, except for the intervening variable effect, are shown in Table 4 according to the results of the regression analysis.

Table 4

Supported or Unsupported Research Hypothesis

\begin{tabular}{lcc}
\multicolumn{1}{c}{ Hypotheses } & Supported/ & $p$ \\
\hline $\mathrm{H}_{1}$ : Authentic Leadership has a positive effect on Organisational Identity. & Supported & $P<.001$ \\
$\mathrm{H}_{2}$ : Authentic Leadership has a positive effect on Goal-Oriented Performance. & Supported & $P<.001$ \\
$\mathrm{H}_{3}$ : Authentic Leadership has a positive effect on Emotional Commitment. & Supported & $P<.001$ \\
$\mathrm{H}_{4}$ : Authentic Leadership has a positive effect on Emotional Intelligence. & Supported & $P<.001$ \\
$\mathrm{H}_{5}$ : Emotional Intelligence has a positive effect on Organisational Identity. & Supported & $P<.001$ \\
$\mathrm{H}_{6}$ : Emotional Intelligence has a positive effect on Goal-Oriented Performance. & Supported & $P<.001$ \\
$\mathrm{H}_{7}$ : Emotional Intelligence has a positive effect on Emotional Commitment. & Supported & $P<.001$ \\
\hline
\end{tabular}




\section{Determination of Intervening Variable Effect in Our Research Model}

Our research model was composed to determine the effects of the intervening variable. Especially, we examined whether there is an effect of Emotional Intelligence on the relationship between independent variable of Authentic Leadership and dependant variables of Organizational Identity Goal-Oriented Performance and Emotional Commitment; Hypotheses established and analyses carried out accordingly (Table 5).

Table 5

Intervening Variable Effects According to Regression Analysis Results

\begin{tabular}{|c|c|c|c|c|c|c|}
\hline & $\begin{array}{l}\text { Independent } \\
\text { Variables }\end{array}$ & Dependent Variables & Standard $\beta$ & $p$ & Adjusted $\mathrm{R}^{2}$ & $F$ \\
\hline \multirow{2}{*}{ Regression } & $\begin{array}{l}\text { Authentic } \\
\text { Leadership }\end{array}$ & \multirow{2}{*}{$\begin{array}{l}\text { Organizational } \\
\text { Identity }\end{array}$} & .46 & .000 & .31 & 140.89 \\
\hline & $\begin{array}{l}\text { Emotional } \\
\text { Intelligence }\end{array}$ & & .20 & .000 & .34 & 80.28 \\
\hline \multirow{2}{*}{ Regression } & $\begin{array}{l}\text { Authentic } \\
\text { Leadership }\end{array}$ & $\begin{array}{l}\text { Goal } \\
\text { Oriented }\end{array}$ & .31 & .000 & .23 & 94.25 \\
\hline & $\begin{array}{l}\text { Emotional } \\
\text { Intelligence }\end{array}$ & Performance & .35 & .000 & .32 & 73.39 \\
\hline \multirow{2}{*}{ Regression } & $\begin{array}{l}\text { Authentic } \\
\text { Leadership }\end{array}$ & Emotional & .45 & .000 & .26 & 105.54 \\
\hline & $\begin{array}{l}\text { Emotional } \\
\text { Intelligence }\end{array}$ & Commitment & .11 & .04 & .26 & 55.31 \\
\hline
\end{tabular}

We have measured the intervening variable effect of Emotional Intelligence in our hypotheses, and it was determined that Emotional Intelligence has no effect on the relationship between independent variable of Authentic Leadership and Emotional Commitment. Although authentic leadership increases the level of emotional commitment of the employees, the effect of intervening variable of emotional intelligence may cause employees emotions to become meaningless or senseless. The sectors of the employees are also important. The results of private sector or the public sector studies may show different outcomes. In the public sector, the employees may have emotional commitment to the organizations naturally. Although employees in the public sector have no fear of losing their jobs, those in the private sector are afraid to lose their jobs. In this case, it is not expected that the emotional commitment to be generated naturally or willingly. Table 6 shows the supported and unsupported research hypotheses.

Table 6

Supported or Unsupported Research Hypothesis

\begin{tabular}{lcc}
\multicolumn{1}{c}{ Hypotheses } & Supported/ & $p$ \\
\hline $\mathrm{H}_{8}$ : Emotional Intelligence has an intervening variable effect on the relationship between & Supported & $p<.001$ \\
Authentic Leadership and Organisational Identity. & & \multirow{2}{*}{$\begin{array}{l}\text { Unsuported } \\
\mathrm{H}_{9} \text { : Emotional Intelligence has an intervening variable effect on the relationship between }\end{array}$} \\
$\begin{array}{l}\text { Authentic Leadership and Goal-Oriented Performance } \\
\mathrm{H}_{10} \text { : Emotional Intelligence has an intervening variable effect on the relationship between } \\
\text { Authentic Leadership and Emotional Commitment }\end{array}$ & \multirow{2}{*}{ Unsupported } \\
\hline
\end{tabular}

There is a significant and positive effect of intervening variable of Emotional Intelligence on the relationship between Authentic Leadership and Organizational Identity. This supports the perception of employees' organizational identity positively. At the same time, there is a positive and significant effect of intervening variable of Emotional Intelligence on the 
relationship between Authentic Leadership and Goal-Oriented Performance. Emotional intelligence is positively related to Goal-Oriented Performance of the employees.

\section{Discussion}

The role of Authentic Leadership brings together the positive aspects of the leader and highly developed organizational context. This study argues that Authentic Leadership have an important role in achieving good and lasting results, promoting organizational identity, emotional commitment and goal-oriented performance, as suggested by George and Zhou (2007). Researchers found out that there is a positive relationship between authentic leaders and employees (Alshammari, Almutairi, \& Thuwaini, 2015), and it results in better creativity and performance of the employees (Karatepe \& Aga, 2013). The result of the study show that authentic leadership affects the organizational identity, goal-oriented performance and emotional commitment of the employees positively. Based on the idea that it may influence the attitudes of the employees and outcomes, a similar perspective is adopted for the leader member exchange. However, in order to support the results of the study with the theories, it is necessary to examine both the attitudes and behaviours of white collar and blue collar employees in different sectors. Berman and West (2008) describe Emotional Intelligence as the ability of recognizing his/her own feelings and understanding oneself and others. However, it is determined that emotional intelligence has no intervening variable effect on the emotional commitment. This reveals the fact that employees show different behaviors depending on the organizational structure and cultural characteristics. Balamohan, Tech, and Gomathi (2015) observed that individuals who are emotionally intelligent are more successful when managing their projects and their subordinates and have a strong influence on the outputs of their projects. This finding also supports the positive reaction of the employees, who work with goal-oriented performance in the case of emotionally intelligent.

According to the results of the present study, although there is a significant relationship between authentic leadership and emotional commitment, this relationship broke down and became meaningless under the intervening variable effect of emotional intelligence. It indicates that emotional commitment of the employees disappears in the case of emotional intelligence. Obviously, this can be due to the environmental impacts and the negative situations that can be experienced within the organization. If employees have low level of goals, it is likely that they will spend minimum effort and set low targets for themselves. Vandewalle, Cron, and Slocum (2001) indicate that goal-oriented employees are more proactive, develop their skills for challenging tasks, adapt to new environments, process feedbacks effectively and are open to new ideas. Mowday, Porter, and Steers (1982) and Reichers (1985) proved that emotional commitment has significant and negative relationship with staff turnover, absenteeism, looking for other job alternatives and leaving work. We believe that sample of this study is not at sufficient enough in terms of the distribution and numbers. The study should be carried out by categorizing public and private sector and differentiating production and service sectors. If leadership style is effective, emotional commitment of employees is important for ensuring the organizational performance and reaching goals. The impact of different leadership roles on employees should be analyzed through comparative analyses. This will make it easier to understand the differences between employees' attitudes and behaviors in the organizations. 


\section{Conclusion and Suggestions}

This study was conducted on white collar workers working in private and public organizations and it was determined that there are positive and significant relationships between the independent variables of Authentic Leadership and Emotional Intelligence and dependent variables of Organizational Identity, Goal-Oriented Performance and Emotional Commitment between individuals and in the organisation in general. Empirical evidence suggests that authentic leaders communicate strongly with their employees and gain their strong organizational commitment and organizational citizenship. The results of the study are also in this direction and show that authentic leadership ensures emotional commitment of the employees and affects employee performance significantly in the positive direction. Some studies show that authentic leadership has a positive effect on the organization performance (Wong \& Laschinger, 2013). A study was conducted about emotional intelligence by Jordan and Troth in 2004, they argued that leadership is an important factor in the relationship between employees and their organizations. In addition, a study was conducted by Carmeli in 2003 about the relationship between management of senior executives and emotional intelligence and it was established that the leaders with high levels of emotional intelligence can easily resolve problems with employees. The findings of our study show similar results, but we also believe that the effects of emotional intelligence on employees should be examined in different sectors.

The psychological tie between the organization and the employees results in keeping employees' intention to leave at minimum level and ensures that they work for the organization with more devotion. Moreover, organizational identity is highly related to the employees to stay in the organization (Tang et al., 2014). The leadership in organizations plays an important role in achieving this. In our study, it was specified that authentic leadership has a positive effect on organizational identity. However, we believe that comparative analysis of different leadership roles is necessary. When we look at the results of goal-oriented performance, employees behave in line with the objectives no matter how challenging their tasks are. However, if the employees only have goal-oriented performance, they spend necessary effort to achieve success by reaching their goals, but they do not want to face difficult situations and feel that they do not have sufficient competence in challenging situations (Kim \& Lee, 2013). In our study, the individuals with goal-oriented performance respond positively under the effects of authentic leadership and emotional intelligence.

An employee with emotional commitment feels happy to be member of the organization and think herself/himself as part of the organization and therefore he/she does not consider resigning (Meyer \& Herscovitch, 2001). Meyer et al. (2002) argue that emotional commitment has stronger relationship with both individual and organizational variables compared to other types of commitment. However, our results show that the relationships between authentic leadership and emotional commitment variables disappear under the influence of the intervening variable of the emotional intelligence. This is an important issue that needs to be examined in the sectoral sense as well. Specially, the studies should be conducted to identify the factors that affect the emotional commitment of the employees in the public sector. More attention needs to be paid to the effects of the human resources, organization behaviors and 
leadership styles on employees in order to produce better future studies and qualitative research and generate new concepts from the theoretical perspective. It can be possible to obtain new findings and concepts in the field of social sciences, in particular in the field of management and organization, which may arise due to the cultural differences between the regions. Day-today problems of working life cause generation of new leadership/management styles and new academic concepts. It will be possible to acquire new theoretical and analytical concepts that will contribute to the world literature in the future studies by examining the problems experienced in working life more academically and more intensively.

\section{References}

Ağca, V., \& Ertan, H. (2008). Duygusal Bağlılık içsel motivasyon ilişkisi: Antalya'da beş yıldız-lı otellerde bir inceleme [emotional commitment the relationship between intrinsic motivation: a study on five star hotels in Antalya]. Afyon Kocatepe Üniversitesi İ.I.B.F. Dergisi (C. XORT...S II.), 135-156.

Allen, N. J., \& Meyer, J. P. (1990). The measurement and antecedents of affective, continuan-ce and normative commitment to the organization. Journal of Occupational Psychology, 63(1), 1-18.

Alshammari, A., Almutairi, N., \& Thuwaini, F. (2015). Ethical leadership: The effect on employees. International Journal of Business and Management, 10(3), 108-116.

Antonakis, J., Ashkanasy, N. M., \& Dasborough, M. (2009). Does leadership need emotional intelligence? The Leadership Quarterly, 20, 247-261. https://doi.org/10.1016/j.leaqua.2009.01.006

Ashforth, B. E., \& Mael, F. (1989). Social identity and the organization. Academy of Management Review, 14, $20-39$.

Avolio, B. J., Luthans, F., \& Walumba, F.O. (2004). Authentic leadership: Theory building for veritable sustained performance. Working paper, Gallup Leadership Institute, University of Nebraska-Lincoln, Lincoln.

Avolio, B. J., Gardner, W. L., Walumbwa, F. O., Luthans, F., \& May, D. R. (2004). Unlocking the mask: A look at the process by which authentic leaders impact follower attitudes and behaviors. The Leadership Quarterly, 15, 801-823. http://dx.doi.org/10.1016/j.leaqua.2004.09.003.

Avolio, B. J., \& Gardner, W. L. (2005). Authentic leadership development: Getting to the root of positive forms of leadership. The Leadership Quarterly, 16, 315-338. http://dx.doi.org/10.1016/j.leaqua.2005.03.001.

Azanza, G., Moriano, J.A., Molero, F., \& Lévy Mangin, J.P. (2015). The effects of authentic leadership on turnover intention. Leadership and Organization Development Journal, 36(8), 955-971.

Balamohan, P., Tech, M., \& Gomathi, S. (2015). Emotional intelligence-Its importance and relationship with individual performance, team-effectiveness, leadership and marketing effectiveness. Mediterranean Journal of Social Sciences, 6(1), $120-128$.

Bar-On, R. (1997). Bar-on Emotional Quotient Inventory (EQ-i): Technical manual, multi-health systems. Toronto, Canada: Multi-Health Systems, Inc.

Bar-On, R. (2001). Emotional intelligence and self-actualization. In J. Ciarroch1, J. P. Forgas, \& J. D. Mayer (Eds.), Emotional intelligence in everyday life (pp. 82-97). Philadelphia: Taylor and Francis.

Bar-On, R. E., \& Parker, J. D. (2000). The bar-on emotional quotient inventory: Youth version (EQ-i:YV) technical manual. Toronto, Canada: Multi-Health Systems, Inc

Bell, J. (1993). Doing your research project, (2nd. Edition). Buckingham: Open University Press.

Bell, S. J., \& Menguc, B. (2002). The employee-organization relationship, organizational citizenship behaviors, and superior service quality. Journal of Retailing, 78(2), 131-146.

Berman, E. M., \& West, J. P. (2008). Managing emotional intelligence in US cities: A study of social skills among public managers. Public Administration Review, 68(4), 742-758.

Boyatzis, R. E., Goleman, D., \& Rhee, K. (2000). Clustering competence in emotional intelligence: Insights from the Emotional Competence Inventory (ECI). Handbook of Emotional Intelligence, 99(6), 343-362.

Brett, J. F., \& VandeWalle, D. (1999). Goal orientation and goal content as predictors of performance in a training program. Journal of Applied Psychology, 84(6), 863-873.

Brown, K. G. (2001). Using computers to deliver training: Which employees learn and why? Personnel Psychology, 54(2), 271-296.

Büyüköztürk, Ş. (2005). Anket Geliştirme [Survey Development]. Türk Eğitim Bilimleri Dergisi, 3(2), 133-151. 
Carmeli, A. (2003). The relationship between emotional intelligence and work attitudes, behavior and outcomes: An examination among senior managers. Journal of Managerial Psychology, 18, $788-813$. https://doi.org/10.1108/02683940310511881

Caza, A., \& Jackson, B. (2011). Authentic leadership. In D. Bryman, K. Collinson, B. Grint, B. Jackson, \& M. UhlBien (Eds.), Sage handbook of leadership (pp. 350-362). Thousand Oaks, CA: Sage.

Çeri-Booms, M. (2012). How can authentic leaders create organizational identification? An empirical study on Turkish employees. International Journal of Leadership Studies, 7(2), 172-190.

Cho, J., \& Dansereau, F. (2010). Are transformational leaders fair? A multi-level study of transformational leadership, justice perceptions, and organizational citizenship behaviors. Leadership Quarterly, 21, 409-421.

Çelik, H. C., \& Bindak., R. (2005). İlköğretim okullarında görev yapan öğretmenlerin bilgisayara yönelik tutumlarının çeşitli değişkenlere göre incelenmesi [Examination of the attitudes of teachers working in primary schools towards computer based on various variables]. Eğitim Fakültesi Dergisi, 6(10), 27-38.

Deiner, C. I., \& Dweck, C. A. (1978). An analysis of learned helplessness: Continuous changes in performance, strategy, and achievement cognitions following failure. Journal of Personality and Social Psychology, 36, 451-462

Dragoni, L. (2005). Understanding the emergence of state goal orientation in organizational work groups: The role of leadership and multilevel climate perceptions. Journal of Applied Psychology, 90(6), 1084-1095.

Duarte, M. B. (2015). Organisational and professional commitments: the influence in nurses organisational citizenship behaviours. Tékhne Review of Applied Management Studies, 13(1), 2-11.

Dutton, J. E., Dukerich, J. M., \& Harquail, C. V. (1994). Organizational images and member identification. Administrative science quarterly, 39(2), 239-263.

Dweck, C. S. (1986). Motivational processes affecting learning. American Psychologist, 41(10), 1040-1048.

Gardner, W. L., Cogliser, C. C., Davis, K. M., \& Dickens, M. P. (2011). Authentic leadership: a review of the literature and research agenda. The Leadership Quarterly, 22(6), 1120-1145.

George, J., \& Zhou, J. (2007). Dual tuning in a supportive context: joint contributions of positive mood, negative mood, and supervisory behaviors to employee creativity. Academy of Management Journal, 50(3), 605-622.

Glavas, A., \& Godwin, L. N. (2013). Is the perception of goodness good enough? Exploring the relationship between perceived corporate social responsibility and employee organizational identification. Journal of Business Ethics, 114, 15-27.

Goleman, D. (1995). Emotional intelligence: Why it can matter more than IQ. New York, NY: Bantam Books.

Gutierrez, B., Howard-Grenville, J., \& Scully, M. A. (2010). The faithful rise up: split identification and an unlikely change effort. Academy of Management Journal, 53, 673-699.

Gürbüz, Sait (2006). Örgütsel vatandaşlık davranışı ile duygusal bağlılık arasındaki iliş-kilerin belirlenmesine yönelik bir araştırma [A study to determine the relationship between organizational citizenship behavior and emotional commitment]. Ekonomik ve Sosyal Araştırmalar Dergisi, 3(1), 48-75.

Hair, J. F., Robert, P. B., \& David, J. O. (2000) Marketing research, International Edition. Pennsylvania: Irwin McGraw-Hill.

Hsiung, H. H. (2012). Authentic leadership and employee voice behavior: A multi-level psychological process. Journal of Business Ethics, 107, 349-361.

Ilies, R., Morgeson, F. P., \& Nahrgang, J. D. (2005). Authentic leadership and eudaemonic well-being: understanding leaderfollower outcomes. The Leadership Quarterly, 16(3), 373-394.

Janssen, O., \& Van Yperen, N. W. (2004). Employees' goal orientations, the quality of leader-member exchange, and the outcomes of job performance and job satisfaction. Academy of Management Journal, 47(3), 368-384.

Johnson, R. (1980). Elementary Statistics (third edition), Belmont: Wadsworth Inc.

Jordan, P. J., \& Troth, A. C. (2004). Managing emotions during team problem solving: EI and conflict resolution. Human Performance, 17, 195-218. https://doi.org/10.1207/s15327043hup1702_4

Karatepe, O. M., \& Aga, M. (2013). The effect of job resourcefulness on role stress, emotional exhaustion and overall performance: a study of frontline bank employees. Journal of Financial Services Marketing, 18(2), 91-105.

Kernis, M. H. (2003). Toward a conceptualization of optimal self-esteem. Psychological Inquiry, 14, 1-26. http://dx.doi.org/10.1207/S15327965PLI1401_01.

Kerr, R., Garvin, J., Heaton, N., \& Boyle, E. (2006). Emotional intelligence and leadership effectiveness. Leadership and Organization Development Journal, 27(4), 265-279.

Kim, T. T., \& Lee, G. (2013). Hospitality employee knowledge-sharing behaviours in the relationship between goal orientations and innovative work behaviour. International Journal of Hospitality Management, 34, 324-337. 
Kohli, A. K., Shervani, T. A., \& Challagalla, G. N. (1998). Learning and performance orientation of salespeople: the role of supervisors. Journal of Marketing Research, 263-274.

Latham, G. P., \& Locke, E. A. (1991). Self-regulation through goal setting. Organizational Behavior and Human Decision Processes, 50, 212-247.

Linquist, E. F. (1989). İstatistiğe giriş (H. Çev \& T. Tan, Trans.) [Introduction to statistics]. İstanbul: MEB Öğretmen Kitapları Dizisi, 162.

Lopes, P. N., Salovey, P., \& Straus, R. (2003). Emotional intelligence, personality and the Perceived quality of social relationships. Personality and Individual Differences, 35(3), 641-658. https://doi.org/10.1016/S0191-8869(02)00242-8

Mael, F., \& Ashforth, B. E. (1992). Alumni and their alma mater: a partial test of the reformulated model of organizational identification. Journal of Organizational Behavior, 13, 103-123.

Majeed, N., Ramaya, T., Mustamil, N., Nazri, M., \& Jamshed, S. (2017). Transformational leadership and organizational citizenship behavior: Modeling emotional intelligence as mediator. management and marketing. Challenges for the Knowledge Society, 12(4), 571-590. DOI: 10.1515/mmcks-2017-0034.

Mayor, J. D., \& Salovey, P. (1997). What is emotional intelligence? In P. Salovey \& D. J. Sluyter (Eds.), Emotional development and emotional intelligence: Educational implications (pp. 3-31). New York, NY: Basic Books.

Maxwell, G., \& Steele, G. (2003). Organizational commitment: A study of managers in hotels. International Journal of Contemporary Hospitality Management, 15(7), 362-369.

Melita Prati, L., Douglas, C., Ferris, G. R., Ammeter, A. P., \& Buckley, M. R. (2003). Emotional intelligence, leadership effectiveness, and team outcomes. The International Journal of Organizational Analysis, 11(1), 21-40.

Meyer, J. P., \& Allen, N. J. (1991). A three-component conceptualization of organizational commitment. Human Resource Management Review, 1(1), 61-89.

Meyer, J. P., \& Allen, N. J. (1997). Commitment in workplace, theory, research and application. Thousand Oaks, Calif: Sage Publications.

Meyer, J. P., Herscovitch, L. (2001). Commitment in the workplace toward a general model. Human Resource Management Review, 11, 299-326.

Meyer, J. P., Stanley, D. J., Herscovitch, L., \& Topolnytsky, L. (2002). Affective, continuance, and normative commitment to the organization: A meta-analysis of antecedents, correlates, and consequences. Journal of Vocational Behavior, 61(1), 2052 .

Moon, T. W., Hur, W. M., Ko, S. H., Kim, J. W., \& Yoon, S. W. (2014). Bridging corporate social responsibility and compassion at work: Relations to organizational justice and affective organizational commitment. Career Development International, 19(1), 49-72.

Mowday R. T., Porter L. W., \& Steers R. M. (1982). Employee-organization linkages: The psychology of commitment, absenteeism, and turnover. American Journal of Sociology, 88(6), 1315-1317.

Neider, L. L., \& Schriesheim, C. A. (2011). The authentic leadership inventory (ALI): Development and empirical tests. The Leadership Quarterly, 22(6), 1146-1164. DOI: 10.1016=j.leaqua.2011.09.008

Nikolaou, I., \& Tsaousis, I. (2002). Emotional intelligence in the workplace: Exploring its effects on occupational stress and organizational commitment. The International Journal of Organizational Analysis, 10(4), 327-342.

Nunnally, J. (1978). Psychometric methods. New York, NY: McGraw Hill.

Oakes, P. J., Haslam, S. A., \& Turner, J. C. (1994). Stereotyping and social reality. Oxford: Blackwell.

Rawsthorne, L. J., \& Elliot, A. J. (1999). Achievement goals and intrinsic motivation: A meta-analytic review. Personality and Social Psychology Review, 3(4), 326-344.

Reichers, A. E. (1985). A review and reconceptualization of organizational commitment. Academy of Management Review, $10(3), 465-476$

Riketta, M. (2005). Organizational identification: A meta-analysis. Journal of Vocational Behavior, 66(2), 358-384.

Roberson, L., \& Alsua, C. J. (2002). Moderating effects of goal orientation on the negative consequences of gender-based preferential selection. Organizational Behavior and Human Decision Processes, 87(1), 103-135.

Rynes, S. L., \& Gerhart, B. (1990). Interviewer assessments of applicant fit: An exploratory investigation. Personnel Psychol, 43(1), 13-35

Sadri, G. (2012). Emotional intelligence and leadership development. Public Personnel Management, 41(3), 535-548.

Salovey, P., \& Mayer, J. D. (1990). Emotional intelligence. Imagination, Cognition and Personality, 9(3), $185-211$. 
Schaubroeck, J., Peng, A. C., \& Hannah, S. (2013). Developing trust in leaders and peers, relational identity, and the acceleration of organizational identification during entry. Academy of Management Journal, 56, 1148-1168.

Schneider, B., Rief, A. P., \& Guzzo, R. (1996). Creating a climate and culture for sustainable organizational change. Organizational Dynamics, 24(4), 7-19.

Shamir, B., \& Kark, R. (2004). A single-item graphic scale for the measurement of organizational identification. Journal of Occupational and Organizational Psychology, 77, 115-123.

Steele, J. D., Beauregard, R. S., Hoover, P. B., \& Schmidt, A. M. (2000). Goal orientation and task demand effects on motivation, affect, and performance. Journal of Applied psychology, 85(5), 724-738.

Synder, E. E., \& Spreitzer, E. (1984). Identity and commitment to the teacher role. Teaching Sociology, 11(2), 151-166.

Tang, C., Liu, Y., Oh, H., \& Weitz, B. (2014). Socialization tactics of new retail employees: a pathway to organizational commitment. Journal of Retailing, 90(1), 62-73

Thomas, J. R., Nelson, J. K., \& Silverman, S. J. (2005). Research methods in physical activity (5th ed.). Champaign, IL: Human Kinetics.

Wieseke, J., Ullrich, J., Christ, O., \& Van Dick, R. (2007). Organizational identification as a determinant of customer orientation in service organizations. Marketing Letters, 18(4), 265-278.

Wong, C. A., \& Laschinger, H. K. S. (2013). Authentic leadership, performance, and job satisfaction: The mediating role of empowerment. Journal of Advanced Nursing, 69(4), 947-959.

Vandewalle, D. (1997). Development and validation of a work domain goal orientation instrument. Educational and Psychological Measurement, 57(6), 995-1015.

VandeWalle, D., \& Cummings, L. L. (1997). A test of the influence of goal orientation on the feedback- seeking process. Journal of Applied psychology, 82(3), 390-400.

Vandewalle, D., Brown, S., Cron, W., \& Slocum, J. (1999). The influence of goal orientation and self-regulation tactics on sales performance: A longitudinal study. Journal of Applied Psychology, 84(2), 249-259.

Vandewalle, D., Cron, W., \& Slocum, J. (2001). The role of goal orientation following performance feedback. Journal of Applied Psychology, 86(4), 629-640. 